\title{
Social networks in organizations
}

Redes sociais nas organizações

Redes sociales en las organizaciones

José G. Vargas-Hernández

PhDin Economics

$\mathrm{PhD}$ in Public management

- University Center for Economic and Managerial Sciences - University of Guadalajara

- E-mail: jvargas2006@gmail.com

\section{(9) Cecilia Morales-Del-Rio}

- PhD candidate in Administrative Sciences

- University Center for Economic and Managerial Sciences - University of Guadalajara

- E-mail: cecilia.mdelrio@academicos.udg.mx; cecilia.morales@cucea.udg.mx 


\section{Abstract}

Social networks play a key role in communication-related organizations. Unfortunately, the current literature has only been focused on the use of social networks within communities for creation and interaction between the organization and consumers, concerning mostly digital marketing and branding. Much of this literature falls under two interesting perspectives, the importance of communication in organizations and the use of social networks as a new communication channel. Organizations need communication as part of the understanding between management and employees, whereas social networks integrate agents into digital communities. This study summarizes the literature concerning each of these perspectives to derive assumptions and expected results on communication with social networks within organizations. Then, by means of a sociological perspective, the reconciliation of these views considering the incorporation of social networks as a new form of internal communication for organizations is proposed. There is a need for integration of communities with social networks, based on the context of premises made by previous studies.

KEYWORDS: SOCIAL NETWORKING • COMMUNICATION • COMMUNICATION MANAGEMENT • EWOM.

\section{Resumo}

As redes sociais desempenham um papel fundamental nas organizações relacionadas à comunicação. Infelizmente, a literatura atual tem se concentrado apenas no uso de redes sociais dentro das comunidades para criação e interação entre a organização e os consumidores, principalmente em marketing digital e branding. Grande parte dessa literatura se enquadra em duas perspectivas interessantes, a importância da comunicação nas organizações e o uso das redes sociais como um novo canal de comunicação. As organizações precisam de comunicação como parte do entendimento entre a gerência e os funcionários, enquanto as redes sociais integram agentes às comunidades digitais. Este estudo resume a literatura sobre cada uma dessas perspectivas para derivar pressupostos e resultados esperados na comunicação com redes sociais dentro das organizações. Em seguida, por meio de uma perspectiva sociológica, propõe-se a conciliação dessas visões considerando a incorporação das redes sociais como uma nova forma de comunicação interna para as organizações. Há necessidade de integração de comunidades com redes sociais, com base no contexto de premissas feitas por estudos anteriores.

\section{PALAVRAS-CHAVE: REDES SOCIAIS • COMUNICAÇ̃̃O • GESTÃO DE COMUNICAÇÃO・EWOM.}

\section{Resumen}

Las redes sociales desempeñan un papel clave en las organizaciones relacionadas con la comunicación. Desafortunadamente, la literatura actual solo se ha centrado en el uso de las redes sociales dentro de las comunidades para la creación e interacción entre la organización y los consumidores, en lo que concierne principalmente al marketing y el branding. Gran parte de esta literatura se inscribe en dos perspectivas interesantes, la importancia de la comunicación en las organizaciones y el uso de las redes sociales como un nuevo canal de comunicación. Las organizaciones necesitan la comunicación como parte del entendimiento entre la gerencia y los empleados, mientras que las redes sociales integran a los agentes en las comunidades digitales. Este estudio resume la literatura sobre cada una de estas perspectivas para derivar suposiciones y resultados esperados en la comunicación con redes sociales dentro de las organizaciones. Luego, a través de una perspectiva sociológica, se propone la conciliación de estos puntos de vista considerando la incorporación de las redes sociales como una nueva forma de comunicación interna para las organizaciones. Existe la necesidad de integración de las comunidades con las redes sociales, en función del contexto de las premisas realizadas por estudios anteriores. 


\section{INTRODUCTION}

$\mathrm{T}$ he emergence of the Web 2.0 has been driven by strategists, as well as the use of social networks in organizations as a form of communication, which led to the creation of a new communication model. This Web 2.0 is a process of interaction between individuals or social groups involved in its implementation (Cebrián Herreros, 2008). Given this context, companies now develop their own social networks as a way to compete against their rivals and provide added value to their potential consumers (Casaló; Flavián; Guinalíu, 2011).

Web 1.0 and "traditional" media brands have control over information and over access and/or level of interactivity that can be allowed. However, Web 2.0 passes control directly to users on equal terms, and as such users of a social network have control (Cebrián Herreros, 2008). Users define where interest lies and what information or idea is appreciated. This leads organizations to create connections between their users in order to generate information networks. As such, the consumer is an active participant in the exercise of interactivity of multiple chains with immediate feedback and high communication (De Valck; Van Bruggen; Wierenga, 2009).

Digital media has been crucial to revalue brands and to get awareness of user comments, creating a new bonding and social relations instrument (Robles, 2014), which is based on the creation of a social network, sharing activities and enhancing relationships.

But the question is not whether social networks work for communication with stakeholders, as demonstrated in several studies, but if this same new communication system, new way of interaction between social groups can operate within organizations. This article thus focuses on creating a literature review on the use of social networks in today's communication, and tries to understand how organizations are adapting to these changes, and how they might include these same strategies in internal communication.

\section{COMMUNICATION IN ORGANIZATIONS}

Communication comes from Latin comunicare, which means sharing; communicationis meant to exchange data, ideas, experiences, opinions, information, attitudes and feelings between two or more people (Comunicación, 2019). Communication is inherent to human beings, it is the faculty that has the human being to transmitting information, feelings and experiences to one or more people, and this collective interaction molds man, displays something in common, and as such it plays an important role in the development of any human interaction (Rivera et al., 2005). Communication then forms a set of tools, strategies and major actions in the organizational world, and thus proper handling of this tool can become a key factor in the success of organizations today.

Communication helps the understanding between management and employees, trying to combine various interests, expectations and needs, as well as both the development of human talent and the optimization of production (Rivera et al., 2005).

Organizational communication depends on the flow of internal communication that occurs within the organization to establish relationships between individuals. So when communicating doors open in, labor relations develop amidst an atmosphere of sincerity, listening and circulation of information (Gurău, 2008).

In organizations it is essential that there be a democratic, prosper and calm organizational climate, where harmony and respect between managers and other staff is common, and work is recognized, staff are motivated, with such an environment bringing up courage and inspiration to their peers (Del Olmo Arriaga; Fondevila, 2009). 
Accordingly, "information, as a basic resource for development of human relations, must be timely, since it is an essential tool to achieve synergy-oriented actors of different organizational processes and to publicize political, cultural and economic development in social and academic institutions, allowing to enrich the quality of work" (Del Olmo Arriaga; Fondevila, 2009, p.35).

- Proposition 1. Communication within organizations establishes stable relations between individuals of said organization, creating an environment suitable to the development of human talent and production optimization.

Through communication, closer ties can be achieved, contact between staff working in a company is intensified, their participation in creating opportunities and solutions to problems and weaknesses is encouraged; which in turn will help individuals feel involved, considered by their superiors, increasing their motivation which thus may lead to better performance at work; i.e. communication covers all categories of organization and demands action, planning and understanding in all spaces to strengthen these relations (Rivera et al., 2005).

- Proposition 2. Communication in organizations encourages close links and problem solving, increasing work performance.

\section{SOCIAL MEDIA COMMUNICATION}

The internet has allowed people around the world to make personal observations, thoughts and opinions accessible to the community with one click. This lead to the creation of a diverse mosaic of communications, creating communities where people trade experiences and feelings, talking about their favorite products and services, politics and world incidents. Examples of such communities are online forums directed towards product review, instant messaging, discussion groups on the internet, mailing lists, and chat rooms (Dellarocas, 2006).

The notion of an online community is not new. Kannan, Chang and Whinston (2000) mention that at the beginning of the internet, the first online communities were created by researchers who exchanged ideas and information to create collaborative projects.

The concept of network derives from its technical approach that works around the nature of social ties. Social networks represent a source of first-hand information for organizations, because from them it is possible to meet the needs and concerns with which they interact (Casaló; Flavián; Guinalíu, 2011). But in order to achieve these benefits, participation at high levels is required to ensure the long term survival (Uribe Saavedra; Rialp Criado; Llonch Andreu, 2013).

Among the communication strategies used in social networks is the so-called viral marketing, which can be used for the reward of big companies with large budgets, such as SMEs. When viral marketing is used, it can improve the brand proposal, making it more noticeable in the market (Arcos; Gutiérrez; Hernanz, 2014). This is because it has been shown that consumers may be influenced by opinions in online forums ahead of making a purchase decision (Dellarocas, 2006). These views are known as electronic Word-of-Mouth (eWOM). Viral marketing therefore uses eWOM as a form of communication within social networks. Hence, social networks have become a medium for social interactions (Uribe Saavedra; Rialp Criado; Llonch Andreu, 2013).

- Proposition 3. The eWOM employees can influence other employees in decision-making as a strategy used by leaders of management.

From Facebook to Twitter, new networks like Snapchat have exponentially increased the number of users (Keenan; Shiri, 2009), and the eWOM, them. These social networks have a variety of features that facilitate socializing on the internet. Users share, 
songs, reflections, photos, private messages, videos and other kinds of expression publicly. The number of social networking sites has also grown, contributing with different approaches, designs and features to their users (Bigné; Küster; Hernández, 2013).

- Proposition 4. Social networks within the organization serve as a communication form between employees and management as they could share thoughts, problem solving, perspective of future scenarios and other forms of expression that have to do with the daily living of the organization.

Social networks have a specific role within the community, not only because it is a subject of interest for the union of the community, but now all interests are brought together in a single center (Keenan; Shiri, 2009). The previous approach of the social networking era of issues and interests, while the core of social media is people and collective identity (Bigné Küster; Hernández, 2013). In previous social networking environments, a user could focus almost fully on a specific subject of interest, creating a community around it (Sádaba, 2012). Community discussions now focus on the standard interests of the group, with emphasis on issues and community responses (Rejón Guardia, 2013). The social network atmosphere focuses more on the user's identity. Users became involved in niche interest packs and started engaging in communities within the network, the goal being the means for unity. The importance of the issue and the discussion thread are replaced by an emphasis on each user's profile (Balakrishnan; Dahnil; Yi, 2014).

- Proposition 5. Employees and users within the social network of an organization create community identity and improve the interaction and integration thereof, while also allowing for the individuality of the employee.

These users are amateurs with talent or expertise in a particular subject and who publish a large amount of original information in social networks, and are able to help with problem solving and make the organization wiser about consumer decisions (Pérez Dasilva et al., 2013). Internet and this new form of communication increase the ability to influence users, who now acknowledge their own ability to influence in organizations and institutions, since "the role of a subject in the network is given by what it provides them and the value others attach to it, in a process named collective review" (Perez Dasilva, 2013, p.368).

These communities created on social networks are based on content arising from collaborative and participatory work, and consequently the interest of social networks does not focus much in content and its ability to establish valuable relationships (Robles, 2014).

- Proposition 6. Organizations using an internal social network will be creating a collaborative and participatory community, which helps establish valuable relationships apart from the employment relationship.

Internet today is like an ample conversation, and organizations are realizing they have to be present and participate in the conversation, since users are probably wishing to connect and talk to them (Spaulding, 2010). Social networking is a space that enables organizations to connect with customers and talk to them, especially because this conversation allows them to know their customers and learn from them as well as knowing them better and creating stronger bonds with the company, which in turn translates into business results (Rocha et al., 2013).

- Proposition 7. Social networking allowed to establish conversations that enable the better understanding and learning of employees in order to connect and converse with them. 


\section{ADDITIONAL CONTINGENCIES}

Propositions 1-2 suggest the need for communication within organizations. Propositions 3-7 describe the inclusion of social networks as a new form of communication that can lead to the realization of new potential. Therefore, scholars who investigate these hypotheses would do well to incorporate this kind of effect on their models.

\section{CONCLUSIONS}

Given the above so far, there is no doubt that communication within social networks has integrated the usual behavior of people and enjoys great power in our actions and daily habits (Pérez Dasilva et al., 2013). Social networks become a tool to consider in organizational communication strategy, as they could allow employees to contact theim and increasingly spend more time online.

The internet would thus be a communication channel to take into account increasing organizational relationships. The use of social networks by companies is becoming a key part of communication strategies to leverage and "chat" with their consumers (Rocha etal., 2013). As such, why not take the same strategy internally with employees and "chat" with them on this new channel. This article presents some proposals that can help solve different conceptions of a variety of internal communications within an organization.

These arguments have practical implications. If the use of social networks as a channel of communication within organizations has the impact that our assumptions suggest, then certain types of organizations are facing more challenge related to them: specifically, organizations where many channels and branches of significant size exist, where the common denominators are lower because the organization could not generate the expected sense of community. In such conditions, communication and business priorities may differ, and it is advisable to seek options for developing an operating channel in the long term and bring this community into the hands of those who prioritize the value of communication within the organization.

\section{REFERENCES}

ARCOS, Virginia Aguilar; GUTIÉRREZ, Sonia San Martín; HERNANZ, René Payo. La aplicación empresarial del marketing viral yel efecto boca-oreja electrónico. opiniones de las empresas. Cuadernos de Gestión, Bilbao, v.14, n.1, p.15-31, 2014. doi: 10.5295/cdg.120348va.

BALAKRISHNAN, Bamini; DAHNIL, Mohd Irwan; YI, Wong Jiunn. The impact of social media marketing medium toward purchase intention and brand loyalty among generation Y. Procedia: Social and Behavioral Sciences, Amsterdam, v.148, p.177-185, 2014. doi: 10.1016/j.sbspro.2014.07.032.

BIGNÉ, Enrique; KÜSTER, Inés; HERNÁNDEZ, Asunción. Las redes sociales virtuales y las marcas: Influencia del intercambio de experiencias eC2C sobre la actitud de los usuarios hacia la marca. Revista Española de Investigación En Marketing ESIC, Madrid, v.17, n.2, p.7-27, 2013. doi: 10.1016/S1138-1442(14)60022-X.

CASALÓ, Luis; FLAVIÁN, Carlos; GUINALÍU, Miguel. Redes sociales virtuales desarrolladas por organizaciones empresariales: antecedentes de la intención de participación del consumidor. Cuadernos de Economía y Dirección de la Empresa, Amsterdam, v.28, n.1, p.42-51, 2011. doi: 10.1016/j.cede.2011.06.003. 
CEBRIÁN HERREROS, Mariano. La Web 2.0 como red social de comunicación e información. Estudios sobre el Mensaje Periodístico, Madrid, v.14, p.345-361, 2008.

COMUNICACIÓN. In: DICCIONARIO del español jurídico, 2019. Madrid: Real Academia Española. Disponível em: https://bit.ly/30ShGkW. Acesso em: 23 jul. 2019.

DE VALCK, Kristine; VAN BRUGGEN, Gerrit; WIERENGA, Berend. Virtual communities: a marketing perspective. Decision Support Systems, Amsterdam, v.47, n.3, p.185-203, 2009. doi: 10.1016/j.dss.2009.02.008.

DEL OLMO ARRIAGA, José Luis; FONDEVILA, Joan Francesc. La comunicación como herramienta estratégica en la industria de la moda. Revista de Comunicación de la SEECl, Madrid, v.13, n.18, p.1-30, 2009. doi: 10.15198/seeci.2009.18.1-30.

DELLAROCAS, Chrysanthos. Strategic manipulation of internet opinion forums: implications for consumers and firms. Management Science, Baltimore, v.52, n.10, p.1577-1593, 2006. doi: 10.1287/mnsc.1060.0567.

GURĂU, Călin. Integrated online marketing communication: implementation and management. Journal of Communication Management, Bingley, v.12, n.2, p.169-184, 2008. doi: 10.1108/13632540810881974.

KANNAN, P. K; CHANG, Ai-Mei; WHINSTON, Andrew. Electronic communities in e-business: their role and issues. Information Systems Frontiers, New York, v.1, n.4, p.415-426, 2000. doi: 10.1023/A:1010022226639.

KEENAN, Andrew; SHIRI, Ali. Sociability and social interaction on social networking websites. Library Review, Bingley, v.58, n.6, p.438-450, 2009. doi: 10.1108/00242530910969794.

PÉREZ DASILVA, Jesús Ángel et al. Las empresas en Facebook y Twitter. Situación actual y estrategias comunicativas. Revista Latina de Comunicación Social, Santa Cruz de Tenerife, n.68, p.676-695, 2013. doi: 10.4185/RLCS-2013-996.

REJÓN GUARDIA, Francisco. La respuesta del consumidor a la publicidad en redes sociales: análisis del efecto de la presión publicitaria y la experiencia. 2013. Tese (Doutorado) - Universidad de Granada, Granada, 2013.

RIVERA, Alix Belén et al. La comunicación como herramienta de gestión organizacional. Negotium, Maracaibo, v.1, n.2, p.32-48, 2005.

ROBLES, Juan. Mercados municipales y tecnologías digitales: entre el e-comercio y nuevas formas de convivialidad. Anthropologica, Baie-D'Urfé, v.32, n.33, p.137-161, 2014.

ROCHA, Thelma Valéria et al. An exploratory study on the use of social networks in building customer relationships. Review of Business Management, São Paulo, v.15, n.47, p.262-282, 2013. doi: 10.7819/rbgn.v15i47.953.

SÁDABA, Igor. Acción colectiva y movimientos sociales en las redes digitales. Aspectos históricos y metodológicos. Arbor, Madrid, v.188, n.756, p.781-794, 2012. doi: 10.3989/arbor.2012.756n4011.

SPAULDING, Trent. How can virtual communities create value for business? Electronic Commerce Research and Applications, Amsterdam, v.9, n.1, p.38-49, 2010. doi: 10.1016/j.elerap.2009.07.004. 
URIBE SAAVEDRA, Felipe; RIALP CRIADO, Josep; LLONCH ANDREU, Joan. The use of social networks as a marketing tool in the business performance. Cuadernos de Administracion, Amsterdam, v.26, n.47, p.205-231, 2013.

Article received on 12/11/2018 and approved on 12/07/2019. 